\title{
Writing back to colonialism, again: The novel The Chimurenga Protocol and the 'new' resistance literary culture in post-2000 Zimbabwe
}

\begin{abstract}
Author:
Oliver Nyambi ${ }^{1}$

Affiliation:

${ }^{1}$ Department of English, University of Zululand, South Africa

Correspondence to:

Oliver Nyambi

Email:

nyambio@unizulu.ac.za

Postal address:

Postal Bag X1001,

KwaDlangezwa 3886,

South Africa

\section{Dates:}

Received: 11 Mar. 2014

Accepted: 29 July 2015

Published: 02 Oct. 2015

How to cite this article: Nyambi, O., 2015, 'Writing back to colonialism, again: The novel The Chimurenga Protocol and the "new" resistance literary culture in post-2000 Zimbabwe', Literator 36(1), Art. \#1125, 9 pages. http://dx.doi. org/10.4102/lit.v36i1.1125

\section{Copyright:}

(C) 2015. The Authors.

Licensee: AOSIS

OpenJournals. This work is licensed under the Creative Commons Attribution License.
\end{abstract}

Some contemporary Zimbabwean literature demonstrates a discernible resistance thread. These literary works create fictional life-worlds in which the ambivalence of colonial land and economic injustices are exposed as potentially mutating and threatening the independent nation. In this way, such works validate 'nationalist' corrective measures through inserting a narrative that implicitly refers back to past colonial imbalances. In the choreographed discourses of national sovereignty that characterise the Third Chimurenga - epitomised by Mugabe's book Inside the Third Chimurenga - there are perceived dangers from infiltrating forces which pose a threat to the nation's sovereignty. Britain's refusal to fund land reform in Zimbabwe is viewed as an implicit declaration of that country's intention to derail the Zimbabwean people's movement towards total independence and the 'fast track land reform' of the Third Chimurenga. The anti-Britain campaign is inextricably linked to the land question. The cultural sphere (especially its literary, theatrical and musical dimensions) in Zimbabwe's recent past has been faced with the political urgency of (re)defining the land question. Literary texts such as Nyaradzo Mtizira's novel The Chimurenga Protocol, theatre performances such as Christopher Mlalazi's 'Election Day' and musical compositions by the war veteran singer Dickson Chingaira are some of the artistic productions that reveal conflicting perspectives on the land and its significance in the people's search for selfdetermination and national identity. Using the example of Nyaradzo Mtizira's novel The Chimurenga Protocol, this article argues that whilst many Zimbabwean writers published in the post-2000 period have attempted to imagine 'alternative' national identities, the text's anti-West thematic and aesthetic texture resonates with the state's post-2000 ideological grand narratives of the nation and can therefore be read as the newest form of resistance literature in Zimbabwe's postcolonial literary oeuvre.

Nogmaals terugskryf teen kolonialisme: Die roman The Chimurenga Protocol en die 'nuwe' literêre versetskultuur in post-2000-Zimbabwe. Sommige kontemporêre Zimbabwiese literêre werke toon 'n duidelike versetstendens. Hierdie letterkundige werke skep fiktiewe wêrelde waarin die ambivalensie van koloniale grond- en ekonomiese onreg uitgelig word as potensieel muterende en bedreigende invloede op die onafhanklike nasie. Hierdie werke regverdig 'nasionalistiese' korrektiewe maatreëls deur 'n narratief wat implisiet terugverwys na koloniale wanbalanse van die verlede. In die gechoreografeerde diskoerse van nasionale sowereiniteit wat die Derde Chimurenga kenmerk en in te voeg wat verpersoonlik word deur Mugabe (2001) se boek Inside the Third Chimurenga - is daar vermeende gevare komende van infiltrerende magte wat ' $n$ bedreiging vir die nasie se sowereiniteit inhou. Die kulturele sfeer (veral die letterkundige, teater- en musikale dimensies daarvan) in Zimbabwe se onlangse verlede het al 'n tyd lank te kampe met die polities dringende uitdaging om die grondvraagstuk te (her)definieer. Deur Nyaradzo Mtizira se roman The Chimurenga Protocol as voorbeeld te gebruik, voer hierdie referaat aan dat, hoewel baie Zimbabwiese skrywers gepubliseer in die post-2000-tydperk gepoog het om 'alternatiewe' nasionale identiteite te bedink, die teks se anti-Westerse tematiese en estetiese tekstuur met die staat se ideologiese grootse narratiewe van die nasie post2000 resoneer en dat dit dus gelees kan word as die nuutste vorm van versetletterkunde in Zimbabwe se postkoloniale letterkunde-oeuvre.

\section{Introduction}

In defense of his characterisation of 'the novelist as teacher' in relation to his novel Anthills of the Savannah's uncompromising critique of emerging military regimes in Africa, Achebe (1997:141) described his notion of the 'good teacher [as the one who] draws out ... leading out, helping the 
pupil to discover ... to explore' (emphasis as in the original). Implicit in Achebe's argument here is the 'guiding' facet to narrative also identified by B. Carr (1999) as facilitating the process of perspectival sharing between the reader and the writer. I invoke this notion of the narrative's 'guiding' capability to read The Chimurenga Protocol (Mtizira 2008) as a resistance literary text that consciously 'guides' its readers to a sympathetic relationship with the state's grand political project of the Third Chimurenga. ${ }^{1}$ This grand political project aims at eliminating 'inauthentic' or anti-state citizens and 'reestablishing' the indigenes' total sovereignty through land reclamation and resettlement.

My major thrust is to explore the uniquely post-2000 ways in which the novel The Chimurenga Protocol (unlike the majority of texts published in the post-2000 period which covertly and overtly censor and attack the ZANU-PF regime and its policies) ${ }^{2}$ defends the political establishment by affectively leading us to understand the post-2000 land reforms as genuine and imperative for total decolonisation. I read Nyaradzo Mtizira's novel as a 'neo-nationalist ${ }^{\prime 3}$ novel which discursively counters anti-state discourses that contested the state's sites of political legitimacy in post-2000 Zimbabwe. My notion of counter-discourse is informed by Tiffin's (1995) conception of it as:

involv[ing] a mapping of the dominant discourse, a reading and exposure of its underlying assumptions, and the dis/mantling of these assumptions from the cross-cultural standpoint of the imperially subjectified "local". (p. 98)

I view The Chimurenga Protocol as constructing a complex discursive life-world ${ }^{4}$ in which the state's Third Chimurenga discourse is not only validated but also defended, highlighting the inseparability of the post-2000 literary and political texts. Broadly, my analysis follows Chinua Achebe's (1988:40) postcolonial conception of the 'teaching' potentialities of novelists in his essay, 'The novelist as Teacher', to explore not only the connection between literary narratives and land politics in post-2000 Zimbabwe but also the tensions inherent in writing back to colonialism in the 21st century.

Much akin to Tiffin's (1995) notion of 'counter discourse' is the concept of 'writing back', which can be traced back to Ashcroft, Griffiths and Tiffin's (1989) seminal text The empire writes back: Theory and practice in post-colonial literatures. The text has significantly influenced the ways in which

1.The Third Chimurenga (the third liberation war) denotes the land resettlement programme instituted by the ZANU-PF government in the early 20th century. The programme involved the mass acquisition of white-owned land for the resettlement of black people. Many scholars (Raftopoulos 2009) attribute the resultant economic crisis, which reached peak level in 2008, to this programme whilst the ZANU-PF government blames Western sanctions for the malaise.

2.I am thinking of texts such as Brian Chikwava's novel Harare North (2009), Julius Chingono's short stories and poetry in his collection Not another day (2006), Chenjerai Hove's poetry in Blind moon (2003), Edgar Tekere's autobiography A lifetime of struggle (2007). These texts situate their imagined or fictional life-worlds in a clearly post-2000 Zimbabwean setting in which state authoritarianism portends the national economic and political cataclysm.

3.I am using 'neo-nationalist' in this context to refer to the resurgent form of resistance discourse used by the state which is steeped in liberation war nationalism.

4.I am using the phrase 'life-world' in the sense of Pleßke's (2014:162) understanding of it as a created 'narrated story-world' which can be contrasted with the real world. literature by the colonised and formerly colonised are read and interpreted. 'Writing back' to the empire is a conscious effort by colonised and formerly colonised people to use imaginative literature to unsettle what Ashcroft et al. have called 'the privileging norm' (p. 3) ascribed to English literature and culture. In 'writing back', the colonised and formerly colonised people invoke their local modes of perceiving world phenomena to produce a literary aesthetic that contests English literature's usage as a colonial paraphernalia for 'the denial of the value of the "peripheral", the "marginal", the "uncanonized"' (Ashcroft et al. 1989:3). The colonised's effort is informed by the understanding that amongst other things, imaginative literature could be used at what Ashcroft et al. call the 'level of simple utility as propaganda' (p. 3) to destabilise colonialism almost in the same sociocultural way that English literature developed as an ally of the Empire project. Scott (1990:45) posits that 'relations of power are, at the same time, relations of resistance'. However, in the post-2000 period, the relationship between Zimbabwe and the former coloniser Britain has been more complex than the straightforward colonised victim and coloniser victimiser images evoked in 'patriotic' narratives of contemporary Zimbabwe (see Mugabe 2001). Inevitably, the portrayal in state narratives of the Third Chimurenga of the nature of Zimbabwean victimhood and the preferred forms of resistance to it are not anything Scott predicted in his study of domination and resistance. In what Ranger (2004) calls the state's 'patriotic history' ${ }^{5}$ - a reinscription of history that tactically accentuates the heroics of the ruling elites and dwarfs or elides those of its rivals - the ZANU PF government constructs British 'new colonialism' as manifesting in opposition parties that challenge the hegemony and legitimacy of the liberation movement. As shall become clear later on in the discussion, this narrative of national victimhood is inscribed in the symbolic theft of the Chimurenga Protocol by a black Zimbabwean working in cahoots with British secret agents. For the state (see Mugabe 2001), the 'new' resistance, then, involves a re-invocation of the Chimurenga spirit but this time to target what the ruling party perceives as local merchants of British new colonialism.

My conceptualisation of Mtizira's text as a 'new' ‘writing back' or resistance novel emanates from its apparent validation of the state's Third Chimurenga discourse, particularly its antiWest rhetoric. The newness of this 'writing back' aesthetic is that it is steeped in a past and almost forgotten nationalist discourse and rhetoric which was resuscitated by ZANU-PF mainly as a political gimmick to construct and secure political legitimacy in the face of firming political threats from the opposition. Unlike the early nationalist resistance literature such as Solomon Mutswairo's Mapondera, Soldier of Zimbabwe (1978) and Stanlake Samkange's On trial for my country and Year of the uprising (1966) which mostly fictionalised history, latter writings such as Shimmer Chinodya's Dew in the morning (1982), Chenjerai Hove's Bones (1988) and Yvonne Vera's Nehanda (1993) engaged with colonial oppression and colonial historiography retrospectively and more

5.See also Primorac (2007) and Tendi (2010). 
imaginatively. The Chimurenga Protocol can be viewed as a hybrid of these two 'traditions' in its engagement with the post-2000 land debate and identity construction. Like Mutswairo in his historical novel, Mtizira in the first part of The Chimurenga Protocol often uses a selection of historical events and ZANU-PF rhetoric to create a historically situated narrative which ideologically and aesthetically resonates with the party's post-2000 revival of the Chimurenga discourse. Yet in the second and third parts the novel also simultaneously demonstrates a subtle engagement with the land discourse; the third part of the novel is created as a detective narrative and its plot is built around a symbolic hero and villain whose rivalry and conflicts are inscribed with deeper political, ideological and aesthetical meanings. The nature of the crime (the fraudulent disappearance of the Chimurenga Protocol) and the sacrifices made by the detective in its recovery make the villain and the hero assume symbolic significance. Some theoretical perspectives on the detective genre and the character of the detective hero in particular can illuminate the nature of the symbolism, especially its connection to Mtizira's political grand plan. Wilkinson's (2006:161) insights on the influence of socialist thought on the Cuban detective genre come close to my reading of The Chimurenga Protocol as a Third Chimurenga detective narrative. For Wilkinson, the crime and criminals are often associated with broader social inequity and threat, so much so that the detective hero who is tasked to stop them becomes a social hero:

The Cuban police detective always 'got his man' and it was implicitly understood that in this Manichean battle, the revolutionary hero would be successful in his mission, even if he lost his life in the process. Thus destiny provided a moral victory. ... They (Cuban detective heroes) could not be at odds with their surroundings. Their actions were guided by the highest ideals that could never be questioned. In other words, these heroes could not be differentiated from the socialist totality that surrounded them. (Wilkinson 2006)

The same can be said about the detective hero in The Chimurenga Protocol not least because he represents an anticapital Third Chimurenga ideology which is politically in tune with Cuban socialism. In The Chimurenga Protocol, failure is not an option for the detective hero because his mission is tied up with a broader national role and responsibility. According to the Oxford English Dictionary, a protocol is 'the official procedure or system of rules governing affairs of state or diplomatic occasions' or 'the accepted or established code of procedure or behaviour in any group, organization, or situation'. Thus the major purpose of a protocol is to guide state action. As an adjective the word Chimurenga on the title of the protocol explicates and characterises it. Chimurenga underlies the protocol's significance to national policy and identity vis-à-vis the protocol's connection to Zimbabwe's liberation war and the post-2000 land reforms. This makes the protocol thief Chamunorwa a national threat and Magura (the detective who stops him) a national hero. I will return to the politics of the detective genre in the third part of the novel later on, but for now it is imperative to delineate the interface between The Chimurenga Protocol and ZANU-PF land discourse.
The Chimurenga Protocol is unequivocal in its overt reproduction of political, social and ideological interpretations of the former liberation movement and ruling party, ZANU-PF. The 'Author's Foreword' is a convenient starting point in mapping out an approach to the novel's 'patriotic' tendencies, because it summarises clearly what can loosely be termed the authorial intention. The foreword unambiguously locates the writer's intention within a ZANU-PF political perspective about the facts of the politics of his time-space, especially the Third Chimurenga land reforms. Mtizira states: 'the narrative is a factual narrative based on true events in Zimbabwe's rich history' (p. 11). The author's subjective claim to 'facts' is symptomatic of the master fiction that propels the state's Third Chimurenga narrative. The most evident character of this grand narrative is its 'aspir[ation] to generate and underlie all socially produced meanings' (Primorac 2006:9).

However, Mikhail Bakhtin's (1987:323) notion of novelistic 'semantic open-endedness' refuses the author a monopolistic hold on the semantic reading of his creation. In the essay 'Discourse in the Novel', Bakhtin (1987:341) conceives of the novel as constituted of various 'speech types' (heteroglossia) of which authorial speech is one. Besides the 'authorial speech', there are 'the speeches of narrators, inserted genres, ${ }^{6}$ [and] the speeches of characters' that allow for multiple perspectives into the semantic or thematic unity of the novel (Bakhtin 1987:341). Distinctly at odds with this Bakhtinian conception, in The Chimurenga Protocol I perceive such diverse voices as not only enabling the semantic effect of the novel to be accessed through its 'polyphonic' strands, but more significantly as validating and cementing the novel's semantic effect championed by the 'authorial speech'. My analytical focus is therefore on a semantic reading of the novel that gives especial prominence to the 'authorial speech' and the way other 'speech genres' appear to endorse its semantic effect. Whilst by their complex nature novels are prone to multiple perspectives and analyses, I comprehend The Chimurenga Protocol as demonstrating a discernible crystallisation of 'speech genres' in support of the author's preconceived political intentions to support the ideology and practice of land reform performed through the Third Chimurenga. Such intentionality serves to counter critics of the land reforms and, by extension, to massage and sanitise the ZANU-PF regime.

\section{The convergence of patriotic and literary narratives of resistance}

Nyaradzo Mtizira clearly defines his novel as a metanarrative in the 'service' of the broader Third Chimurenga resistance narrative, particularly the project of land redistribution. This can be inferred early in Mtizira's preface to the novel where he states:

thus the Land Acquisition Act of 2001 is an act of retributive justice to redress past injustice in land distribution. It is

6.The most patent example is the inclusion in the novel of an actual letter written in 1997 by British Secretary of State for International Development, Clare Short. 
certainly not a senseless action as portrayed by hostile western governments and their ill-informed, relentless propaganda machinery. (p. 12)

On the government's foreign policy, Mtizira repeats the state's anti-Western nationalism, even reproducing its modern-day stinging vocabulary in the national president's condemnation of the British government's refusal to fund Zimbabwe's preferred Fast-Track Land Reform programme. The letter ${ }^{7}$ to the Zimbabwean government from then British Secretary for International Development Clare Short in 1997 is perhaps the widest cited source of justification for the state's rapid land acquisitions. Through Short's letter the Tony Blair administration declined the Zimbabwe government's claim that 'Britain has a special responsibility to meet the costs of land purchase in Zimbabwe'. Markedly less talked about, if not completely elided in state discourses on land, is Short's assertion that Britain 'believe[d] that land reform could be an important component of a Zimbabwean programme designed to eliminate poverty [and] would be prepared to support a programme of land reform that was part of a poverty eradication strategy but not on any other basis'. It is clear, then, that Mtizira's declared pro-government stance informs his censure of the British and leads him to describe the British government's decision as 'a cack-handed act of diplomatic lunacy' (p. 12). The evident anger inscribed in his diction appears to inform Mtizira's justification of what he calls 'the retributive justice' (p. 12) of the Third Chimurenga land reform, a trope that permeates the entire novel.

In view of the above, a reading of The Chimurenga Protocol that 'structurally' 'kills' the author, sidelines Mtizira's critique of his own text and attempts to 'close-read' the novel without prioritising the 'authorial speech' may be necessary but is doomed to overlook the novel's intricate affinity to the grand narrative that defines the Third Chimurenga. In its determination to defend the state, the novel immerses itself in an overarching Third Chimurenga discourse, exuding a similar political and ideological resistance flavour. This is particularly manifest in the novel's stylistic appropriation of a tripartite symbolic structure. Form and meaning are inextricably bound up as the narrative is divided into three parts, each symbolically corresponding to the nation's historical stages from the first contact with colonialism to the combat against imperialism that frames the Third Chimurenga epoch. Focus is, however, placed on the ways through which the first and second parts do not merely build up to the final (third) part, but are firmly embedded in dominant, state projections of the Third Chimurenga as a logical and imperative culmination of the First and Second Chimurenga or liberation struggles. I read this relationship between the literary narrative's and the state's rhetoric as underpinning the novel's conscious intention: not only to prop up ZANU-PF and Robert Mugabe's political legitimacy by validating their 'chosen' and 'usable' veins of history to make up the Third Chimurenga, but also to resist criticisms against the government. In the novel's and indeed the 7.The contentious letter is available online at http://www.theguardian.com/politics/ foi/images/0,9069,1015120,00.html
Chimurenga's rhetorical and structural logic (as contrasted with the historical), the interconnectedness of the three parts underlies the novel's overarching invitation to read its final part (aptly tagged 'Operation Mwana Wevhu' ${ }^{8}$ as a teleological finale to the people's struggle against an untenable land and wealth distribution that was anchored on racist constructs.

The tripartite structural compartmentalisation is therefore important to the reader's apprehension of the political and aesthetic vision of the novel, especially considering its political message inscribed in its dedication to 'the gallant soldiers of the First, Second and Third Chimurenga' (p.iv). In entering the time-space of the First Chimurenga and ending with a symbolic 'operation' that successfully deals with 'the empire's treachery' (p. 188), the novel creates an impression that its (political) ending is 'the solution' to the protection of the national interest - the land reform process. As the title of the first part of the novel ('The First Chimurenga 1896-1897') suggests, this fictional narrative is informed by the history of colonial land dispossessions - most importantly the spontaneity of the first popular armed native resistance to colonialism. The second part, titled 'The Empire's treachery', is firmly situated in the historical circumstances of the postindependence era, particularly the 'treachery' of Britain's reneging from the Lancaster House promise to fund land reform in Zimbabwe, Britain's neo-colonial attempts to derail majority rule and Britain's subsequent symbolic defeat at the hands of the Third Chimurenga in the third part of the novel.

The Chimurenga Protocol enters contemporary discourse on national identity construction with a neo-nationalist political worldview that is consistent with the government's projection of the land as the major point of reference in any form of independent national identity formation. The novel (like the grand narrative of the Third Chimurenga) projects the 'Zimbabwean problem' as an offshoot of colonialism and a ceremonial flag independence that has failed to wrest real power - economic freedom - from white former Rhodesians and their progeny. Land reform is thus depicted as the pinnacle of total decolonisation, whose overall effect disentangles black people from a colonially induced material disempowerment that (if unchecked) constantly inhibits them from taking their rightful place as fully decolonised subjects. The Third Chimurenga is characterised by a resurgence of anti-white and anti-Western nationalism. After 2000, this project (re)constructs the 'sins' of Britain's colonial past to justify the struggle for political independence and, most importantly, the re-possession of and re-identification with the land in Zimbabwe. The novel encourages a reimagination of an 'authentic' Zimbabwean identity premised on revolutionary consciousness and a colonially induced vulnerability that can only be sufficiently corrected by land nationalisation and redistribution. The portrayal of colonists and subjugated natives in the first part of the novel reveals a discernible binary opposition between the oppressor and

8.This means 'operation child of the soil' - the mission given to the detective, Magura, to recapture the protocol outlining the land reform process from the Britishsponsored Chamunorwa in the third part. 
the oppressed - a narrative deployment of strategies that configure the native as an undeserving victim of callous foreign land invaders. The binarism is informed by a nativist thinking of space, belonging and power relations. What makes the portrayal of the natives' subjugation even more affective is the fact that they are being 'othered' in their own 'backyard' by foreign colonialists. The native fighter's portrayal as committed to fight the colonialist in spite of the fatal consequences indicates the value placed on freedom. Liberty is thus connected to the native's humanity and its revocation by the colonist is associated with the denial of his humanity. The binarisation, then, evokes in the reader a strong detestation of the colonist and, inversely, a strong valorisation of the rebellious and revolutionary spirit of the native fighter.

The Chimurenga Protocol participates in the contemporary discourse on the politicisation and political significance of national memory and identity as a subtle resistance narrative. As hinted above, in an epoch in which most writers have discursively grappled with the government's intensified authoritarian rule and bankrupt economic policies (see Patricia Alden's 2007 report on post-2000 Zimbabwean writing), The Chimurenga Protocol's antiopposition stance demonstrates a unique departure from contemporary Zimbabwean literary practice. The first chapter of The Chimurenga Protocol begins with a hint at the setting of the narrative, which prepares us for a temporal journey into the colonial past: 'Bulawayo: September 1896' (p. 19). The space and time invoked here are important for an understanding of the narrative's preoccupation with especially awful aspects of the colonial land grabs which are revived and relived in the contemporary Third Chimurenga and projected as justification for the current land reclamation and resettlement policy. The date firmly situates the fictional events of plot in the broader historical and political epoch of the colonial moment where the re-lived experience of plunder, a partial racial legal system and total disregard for the native's humanity assume a certain immediacy and vividness that forcefully intensify the moral reprehensibility of colonial injustices, especially to the modern reader. On the other hand, the place 'Bulawayo' evokes the historical site of the first of the colonists' treacheries (the second of which becomes the locus of the second part of the narrative), where Cecil John Rhodes's emissaries John Moffat and Charles Rudd deceitfully persuaded Lobengula, who was King of the Ndebele kingdom in the southern parts of the country, to sign what became the Rudd Concession that gave Rhodes unlimited access to minerals (and later land) across the country. The setting of Bulawayo, however, can best be read as a hint at the imperative to confront the colonial trick, which is historically signified by the first armed uprising against the British South African Company that resulted in Rhodes's victory against Lobengula and a consequent eruption of nationwide native revolt - the First Chimurenga - in 1896.

What makes the first part of The Chimurenga Protocol a marked contribution to the contemporary Third Chimurenga discourse on race, land, national identity and sovereignty is its preoccupation with depicting black people's estrangement from their land as the stimulus to their revolutionary action. This thematic thread does not strike the reader as new to the Zimbabwean literary corpora. In fact, a good number of Zimbabwean literary works published before and after independence engage with the value and significance of land and the challenges of being estranged from it. Yvonne Vera's novel Nehanda (1993), for instance, deploys the recreated figure of the spiritual medium Nehanda to re-enact not only the material value of land to indigenes, but more importantly their spiritual connection with it, which inspires their craving to regain it. However, the perspectival similarity that such works subtly share with the Third Chimurenga narrative is largely indirect, since their fictional life-worlds are informed by pre-Third Chimurenga urgencies; that is, the text's engagement with the land question has no direct reference to the state's politicisation of the issue. The literary works, then, can be read as 'unconsciously' participating in the Third Chimurenga as its 'unconscious' sites for justification. Robert Muponde (2004b) argues that Zimbabwean literature has invariably demonstrated 'veiled, perhaps unintended, complicities in th $[e]$ "Third Chimurenga" project'.

Conscious of Mtizira's proclamation of ideological intent in the 'Author's Foreword', the reader can easily understand how the fictional account of the First Chimurenga in the first part of the novel is directly informed by the history of colonial land appropriation. It is this dispossession which consequently leads to the justifiable spirit of resistance that is epitomised by the unnamed captured native liberation fighter. The symbolically confrontational relationship between William Mason, the head colonist, and the captive native freedom fighter reveals what is cause and what is effect in the politics and sociology of the oppressor and the oppressed vis-à-vis the dispossession and the consequent fighting spirit to repossess land. Mason, described as 'an emissary of Cecil John Rhodes, the former Prime Minister of the Cape colony' (p. 21), takes on the face of the colonist in the first part of the novel. It is through Mason's actions, behaviour and principles that the reader is led to experience not only the antipathy of black people to land dispossession and their consequent colonial serfdom, but, more importantly, the rational and moral validity of restoring land (and therefore power) to the indigenous people - the focal themes of the Third Chimurenga and The Chimurenga Protocol. We first encounter Mason when he is described as 'an adventurer in distant climes far away from England' (p. 20), but shown to be suffering his first moment of terror. The object of Mason's dread - the translated war cry of the Chimurenga wars, 'Forward with the struggle for land' (p. 20) - should be interpreted in the context of the novel's re-inscription of the Chimurenga struggles for land and independence. The war cry, which is the first line of the novel, is also markedly in the indigenous Shona language, 'Pamberi ne Chimurenga'. It carries connotations of the Third Chimurenga notion of the 'perpetuity' of the struggle against imperial domination. The slogan, then, casts the native fighters' struggle (Chimurenga)

9.Literally translates as 'Forward with the struggle'. 
as the first in a series of struggles that cascade in purpose and execution and culminate eventually in the 'victories' of post-2000 Third Chimurenga. As shall become clear later on in the discussion, in the novel, this 'victory' over colonialism is achieved in the third part when Magura - a state detective and modern-day Chimurenga hero - manages to foil Britain's machinations to steal the symbolic Chimurenga Protocol.

The native fighter displays a strong distaste of Mason which borders on racism. Even as he is under captivity, he still shows a deep and inherent sense of superiority and fear of contamination by Mason. In Mason, the reader encounters a repulsive and self-important man who is ignorantly carrying the 'White man's burden' in what he considers to be uncharted land. He is depicted as an ambitious, treacherous and overly racist man with a firm conviction that the natives and the land cannot do without him. He is consistently depicted as denigrating the indigenous people, whom he views as an unwarranted impediment to his efforts to expand the British Empire and 'civilisation', as can be inferred in his reaction to the native prisoner's response to his torture:

As Carrington hesitantly translated the prisoner's words ['Pamberi neChimurenga/Forward with the liberation war'], Mason felt a rising tide of fury tinged with a sense of dread. How dare an inferior being talk to me in such a manner, he thought angrily. Here I am, arch-coloniser and torch-bearer of civilisation to darkest Africa. Yet, this native has the gall to tell me that I am a SETTLER. (p. 24)

Mason, in this excerpt, embodies old clichés of imperial myths of civilisation diffusing from Europe to Africa. Read in the context of the Third Chimurenga's objective of jettisoning 'intransigent' white people outside the borders of the 'imagined patriotic and nationalist community' that is Zimbabwe, Mason emerges as supremacist, repulsive and arrogant. Mason's paranoia, arrogance and supremacist colonial mentality revealed by his racist and inhumane treatment of the native soldier enlist the reader's sympathy and respect for the native fighter's undeserved victimhood. The narrative projects Mason (and by implication, all unpatriotic white people) as precarious candidates for citizenship. Mason's depiction as a crude colonist does not merely hint at the racism of his future Rhodesian (and British) progeny that later generations of the captured fighter (represented by Magura in the third part of the novel) would fight, but also foregrounds the Third Chimurenga theme of Britain's history of relentlessly destabilising Zimbabwe. Mason emerges as more than a simple fortune-seeking or civilising agent but as trailblazing Britain's (and Rhodesians') future interests in the country. This is evident in Mason's deliberations at the strategic meeting where he and Cummins are pondering tactics to suppress the native land revolt (the First Chimurenga):

We will not lose this war, Cummins. Her Majesty's Government sanctions our mission and we pledge allegiance to the crown. If we fail to crush this dissent, we may as well pack our bags and return to England as glorious failures. Is that what we want for the future generation of settlers? (p. 34)
Britain's participation in the colonial project, spearheaded by its citizens abroad, is presented in a way that establishes it or (in the context of the author's foreword) confirms its contaminated human rights record. It is this inglorious record of human rights abuses that consequently disqualifies Britain from judging human rights violations in Zimbabwe (as Mtizira overtly argues in the foreword). Mtizira argues that the nation of Zimbabwe remains a stable democratic country that needs no lectures from Western countries that practice the outsourcing of torture' (p. 13). The defensiveness implicit in this 'exposure' of British hypocrisy, for instance, parallels Mugabe's 'advice' to the then British premier, Tony Blair: 'So Blair keep your England and let me keep my Zimbabwe.' ${ }^{\prime 10}$ This defensive trope is actually a distinctive feature of burgeoning reactionary 'patriotic' narratives and metanarratives aimed at creating counter-discourses to global criticism, especially emanating from Britain and other Western nations. In his novel $A$ fine madness, Mashingaidze Gomo (2010) also supports this rejection of the West's dabbling in the internal affairs of Zimbabwe by constructing a narrator cum persona who carves out a sense of the 'idyllic' African soldier awakening to a conviction that he holds the privilege of being the only authentic narrator of the story of his country:

And he knows that Zimbabwe's history has to be told by the spirits of the First Chimurenga who know that no lessons about tolerance can be learnt from invading imperialists who beheaded African people for resisting dispossession and forced labour/He knows that Zimbabwe's history has to be told by the/descendants of the beheaded who know that no lessons on/human rights and tolerance can be taken from a European community. (pp. 40-41)

In The Chimurenga Protocol, Britain's double standards and its continued neocolonial interests (captured in the aptly named second part of the novel 'The Empire's treachery') become the basis for the formulation of nativist counter policies as direct responses to Western imperialism. In the same vein, the exploitative and disempowering effects of colonialism evocatively articulated through the moral bankruptcy and brutality of characters like Mason and Cummins associate the idea of land reform (encrypted in the Third Chimurenga) with a national, pro-people and rational outlook. In state discourses (see Mugabe 2001), this distrust of Britain is also a hegemonic strategy used to politically exclude, suspect and taint the local opposition's constructions and displays of patriotism. The opposition parties, particularly the Movement for Democratic Change, are viewed as neocolonial puppets of Britain and their political agenda as shaped by Britain's perceived machinations to reverse the country's liberation.

The ZANU-PF (2008) election campaign booklet 100 Reasons To Vote ZANU PF and Cde. Robert Mugabe constantly describes the opposition party, the Movement for Democratic Change, as 'foreign funded and foreign driven' (p. 2), thus connecting the party with neocolonial forces whose persistent involvement in Zimbabwean issues justifies the state's call

10.At the 2002 Earth Summit in Johannesburg. 
for patriotic vigilance in defense of national sovereignty. This political thread is conspicuous in The Chimurenga Protocol's construction of the symbolic and aptly-named sell-out character Chamunorwa who works in cahoots with British intelligence agents to steal the Chimurenga protocol and, in tandem, impede the land reclamation and resettlement process. The name Chamunorwa in the Shona language literally translates into 'why are you my adversary?' - a subtle rhetorical question articulating Zimbabwe's indignation with British meddling. Chamunorwa is thus a fallen angel - once a trusted custodian of the Chimurenga protocol who falls to the lure of material greed.

The symbolic significance of the novel's structure is very marked, especially in the second and third parts. The structure helps the reader to situate the 'meaning' of the novel in the broader contemporary discourse surrounding the land question in Zimbabwe and the agenda of this Third Chimurenga. The name of the intelligence operation launched to recapture the protocol, 'Operation Mwana Wevhu', offers an important allusion to the novel's project as a resistance narrative. 'Mwana wevhu' literally translates to 'child of the soil.' Chamunorwa is the 'lost son', the renegade custodian of the protocol, who must be stopped and realigned with his birthright, the land, before he sells it to the British. It would seem, therefore, that Chamunorwa's participation in the unholy alliance with the British makes him lose touch with the land - the very foundation of his being as a Zimbabwean. Hence, the operation is intended to rescue not only the land reform policy, but also Chamunorwa's own wayward and treacherous disposition. The term 'mwana wevhu' was the popular phrase used by (and to identify) supporters of the First and Second Chimurenga wars against the colonial regime and later the native government's land reform programme during the Third Chimurenga. Chamunorwa sells out as he acts in cahoots with the British in the disappearance of the Chimurenga Protocol. It is only through a recovery of the protocol, the template of the struggle, that the Third Chimurenga becomes a success story, a nuanced re-narration.

In The Chimurenga Protocol, genre does not simply 'play a part in a character's predictability [where] a detective must, in principle, find the murderers' (Bal 1999:124), but genre provides a framework through which the 'criminality' of sabotaging the land reform process is vividly apprehended and internalised by the reader. The major sections of the second and third parts of the novel chronicle the disappearance of the Chimurenga Protocol - an essential document that contains the official government policy on land reform - and its dramatic recovery from 'the jaws' of Britain which is keen on destroying it. Hamandishe Chamunorwa, a senior official in the Ministry of Land Reclamation tasked with overseeing and implementing the policy, falls prey to the deceit of British intelligence operatives eager to sabotage the success of land reform in Zimbabwe. But before Chamunorwa can 'sell out' to the British and so handicap the land reform process, Panashe Magura, the super-detective, follows his trail and just manages to foil the capture of the protocol and cut short the premature celebrations of the British. The detective figure projects Magura as the nation's counteractive supremo set to stall British saboteurs. It is through Magura's intelligence operations that British machinations are exposed. Thereafter, Zimbabwe moves towards total decolonisation in the Third Chimurenga epoch. However, the detective figure appears not only literally to bust the British's sabotage machinations, but more importantly (through the symbolic battle of Intelligence Operatives won by Magura against his British counterparts) to demonstrate what the novel projects as the nation's counteractive outmaneuvering of the snags put in the Zimbabwean nation's way as it moves towards total decolonisation in the Third Chimurenga epoch.

The second and third sections of the novel are connected to the first and follow the historical path taken by Zimbabwe from independence up to the post-2000 Third Chimurenga epoch. The sections are not simple crime fiction narratives. They acquire a firm ideological significance in tandem with the novel's overarching determination to support state notions of the Third Chimurenga land reform process and to counter criticisms of the ZANU PF government. The fictional world of crime and punishment is politically loaded with symbolism. Magura's eventual recovery of the protocol from Chamunorwa, the sellout and patriot-turned-British agent, symbolically enacts Zimbabwe's defeat of Western neocolonial machinations. Magura's 'patriotic' disposition is founded on his firm conception of the value of ownership of land. Such ownership signals the attainment of full citizenship and 'true' independence. In this sense, Magura's detective identity does not make him a simple foil to Chamunorwa (the Chimurenga Protocol thief), but functions on a symbolic level as the ideological antithesis to the 'sell-out' disposition of Chamunorwa. The detective and criminal figures are thus invested with ideological meanings and their fates speak to the novel's overarching nationalist and anti-West tone. The impact produced by the juxtaposition of the thief with the detective transcends the oxymoronic relationship of 'traitor' and 'patriot' identities. In fact, as the novel ends and Magura recovers the lost protocol (whilst Chamunorwa dies a disgraceful suicidal death), the attentive reader discovers the novel's political vision. Magura's speech at the end of the novel strikes the reader as a blatant re-inscription of the ZANU-PF's political line of the past decade and supports the novel's few moments of pro-ZANU-PF sympathies. Magura's speech and the concluding remarks that follow demonstrate a fusion of the vision embedded in the constructed world of the novel and the real Third Chimurenga grand narrative. This can be deduced from the following quotation:

Magura went on. Ever since 1896 every action directed by the British government towards indigenous Zimbabweans has been informed by a mix of greed and racial prejudice. But I am happy to say that the sovereign nation of Zimbabwe remains impregnable to colonial chicanery. The legacy of the Third Chimurenga is economic freedom and our people will enjoy the fruits of this momentous victory. Our President is an African icon, a courageous man who is ahead of his time. Future generations will thank him whole heartedly for his vision of a free and economically unfettered Zimbabwe, ... Magura read 
the [newspaper] headline: LAND REFORM RESTORES DIGNITY AND WEALTH TO THE PEOPLE. (p. 244)

In such instances of banal but patent pro-establishment rhetoric and other overt political allusions (like references to the historical Clare Short's letter) the reader confirms the novel as a text produced to support the land reform process in Zimbabwe. This novel circulates a narrative that bolsters the incumbent president's grandiose vision and broaches no opposition to the state's security apparatus.

Mtizira's penchant for including references to historical events and processes may seem to create problems of historicity and the politicisation of cultural memory. This attribute also troubles the attendant controversies of selectivity in his inclusions, exclusions, fictional distortions and erasures. Edward Said (1993) has hinted at the slipperiness of 'the past' in imagining the nation's present and future:

Appeals to the past are among the commonest of strategies in interpretations of the present. What animates such appeals is not only disagreement about what happened in the past and what the past was, but uncertainty about whether the past really is past, over and concluded, or whether it continues, albeit in different forms, perhaps. This problem animates all sorts of discussions - about influence, about blame and judgment, about present actualities and future priorities. (p. 1)

Said's reflections on the potential influence of the past resonates with the Zimbabwean post-2000 political situation and The Chimurenga Protocol's political overarching theme. As Sabelo Ndlovu-Gatsheni (2011:3) argues, in post-2000 Zimbabwe the ruling ZANU-PF party instituted fixed national identity constructs of patriots and traitors based on 'the "burden of history" bequeathed by heroes of the 18967 risings'. The Chimurenga Protocol follows on this grand narrative circumscribed by the state, invoking the past to fixatedly delineate patriots as supporters and traitors as opposers of the Third Chimurenga. Mtizira's novel therefore requires that one goes beyond reading it as simply a 'narrative impos[ing] on the events of the past a form that in themselves they do not have' (D. Carr 1986:11). This novel is a conscious rendering of selectively imagined references to recognisable empirical events, processes and ideas. In its palpable determination to celebrate the success of the native political establishment and its land reform programme, the novel tactically erases some of the ugly facets of the land reform process (particularly its partisan and disorderly manner) that are commonly cited in oppositional political discourses.

Besides the overt political allusions linking The Chimurenga Protocol to the state's Third Chimurenga narrative, the novel corroborates a rehearsed sense of national history that dichotomises black and white, patriot and traitor. Characters are thus framed on likeable and unlikeable traits. In the first part, the unnamed freedom fighter is sympathetically depicted as an undeserving victim of Western colonialism, giving a clear impression of the rationale of his revolutionary commitment, whilst his white captors are repulsive, showing their malignity. Muponde (2004a) finds this kind of victim-victimiser trope to be omnipresent and dominant in nationalist memorialisation and as sustained discursive strategy in the hegemonic claims to legitimacy of the Third Chimurenga epoch:

At the center of this quest for victimhood is not only the desire to accumulate legitimising symbolic capital, but a deep-seated phobia of living the life of the victimized. It is as if it is impossible to rule if one has not been a victim. Rulership itself is based on the institutionalised and memorialised fear of being a victim again. (p. 179)

The notion of liberation war sacrifice underlines ZANU-PF's discourse of political inclusion and exclusion. It is etched in the Third Chimurenga as the perpetual locus around which party and national political ethos revolve and this gives veterans of the liberation war a claim to political legitimacy which they have exercised, often violently, since the real political threat to their rule emerged with the formation in 1999 of the Movement for Democratic Change. The liberation war sacrifice is inscribed onto national history as a patriotic gesture that every citizen must remember and embrace as an integral part of their national identity. This reverent attitude to the liberation struggle and its heroes' sacrifice is evoked in The Chimurenga Protocol, through the celebratory tone in which the native liberation fighter refuses to bow down to the colonialist's domination. The novel suggests clear narrative directives as to where the reader's sympathies should lie. The native prisoner remains 'unscathed from an intensive session of torture carried out by his British captors' (p. 19). In his defence, the prisoner speaks 'in an ascetic, authoritative manner' and 'with an unnerving prescience' (p. 24). Even as he is sentenced to hang, he remains 'unperturbed by the summary judgment' and a 'knowing smile spread[s] across [his] face' (p. 26) as he awaits his death. Such affective descriptions serve not merely to portray colonial land dispossessions as an injustice glaringly in need of correction, but are also part of the narrative's 'ideological drill' (Bal 1999:33). They signify and celebrate the native people's resolution to fight back and regain their land. In this vein, the historical interconnection of the first, second and third Chimurenga is replicated in the novel in the form of three symbolic segments where Magura (in the second and third part of the novel) emerges as a reincarnation of the vengeful spirit of the unnamed native liberation war fighter who is killed by the colonial regime of Mason in the first part. To this effect, the novel enters the domain of resistance nationalism which imagines the postcolonial nation as a teleological product of past nationalist oracles - Mbuya Nehanda's prophecy of her bones awakening to reclaim the land from colonialists. ${ }^{11}$

\section{Conclusion}

Bhabha (1990:1) has grappled with the complexities and tensions inhabiting the concept of nation and possibilities for its narration. His theorisation destabilises positivist

11. Mbuya Nehanda was a spiritual medium who inspired the first Chimurenga. It is believed that before her death at the hands of the colonial government she is believed that before her death at the hands of the colonial government she
warned the white settlers that her 'bones would rise again' - a statement signalling the second Chimurenga which would be won by her descendants. 
constructions of the nation as a concept that is stable and which can be fixed, known and narrated. Instead, Bhabha believes in the 'limited image of the nation', which makes it occupy the present and yet at the same time and in many ways be anchored in (and propelled by) the past. However, in post-2000 Zimbabwe, the past occupies a contested political space. Inevitably, narrations of the past bear the political markings of the narrators and political players in Zimbabwe have invoked various instances of the past to construct conflicting arguments about its significance and relevance to the political present. Thus, in the same way that opposition discourses invoke the past to indicate and exploit the gap between ZANU-PF's promises of the liberation struggle and the present dire economic reality, ZANU-PF highlights its members' liberation war sacrifices as the ultimate sign of patriotism. The forces underlying this diametrically opposed political thinking and use and abuse of the past explains the 'patriotic' function of the Chimurenga Protocol in the Third Chimurenga epoch. This is because like ZANU-PF (see Mugabe 2001), the novel fixes past revolutionary acts often exclusively associated with ZANU-PF as the undisputed basis for identifying patriots (ZANU-PF) and enemies of the nation (white people, Britain and the local opposition). In its subtle and at times blatant validation of the ruling elite and its marginalisation of the state's opponents, the novel demonstrates a critical disjuncture both from earlier nationalist writings (such as Chenjerai Hove's Bones and Charles Mungoshi's Waiting for the rain, 1981) and contemporary anti-state and pro-liberal democracy texts which proliferated at the turn of the century. Thus, whilst anti-state writing dominated the 21st century literary and cultural spheres and intensified the voices of opposition, The Chimurenga Protocol stands starkly in contrast to these tendencies, their political and social critique and their imagined alternative political dispensations.

\section{Acknowledgements Competing interests}

The author declares that he has no financial or personal relationships that may have inappropriately influenced him in writing this article.

\section{References}

Achebe, C., 1988, Hopes and impediments: Selected essays, Doubleday, New York.

Achebe, C., 1997, 'Interview with Jane Wilkinson', in B. Lindfors (ed.), Conversations with Chinua Áchebe, pp. 141-154, University Press of Mississippi, Jackson.

Alden, P., 2007, Dies Irae: Days of wrath, days of crisis: A report on the current situation in Zimbabwean creative writing, viewed 18 December 2013, from http://www. nai.uu.se/research/finalized_projects/cultural_images_in_and_of/zimbabwe/ patricia-alden-on-creativ/
Ashcroft, B., Griffiths, G. \& Tiffin, H., 1989, The empire writes back: Theory and practice in postcolonial literatures, Routledge, London.

Bakhtin, M., 1987, Speech genres and other late essays, University of Texas Press, Austin.

Bal, M., 1999, Narratology, introduction to the theory of narrative, University of Toronto Press, Toronto.

Bhabha, H.K., 1990, 'Introduction: Narrating the nation', in H.K. Bhabha (ed.), Nation and Narration, pp. 1-7, Routledge, London.

Carr, B., 1999, 'Pity and compassion as social virtues', Philosophy 74(289), 411-429.

Carr, D., 1986, 'Narrative and the real world: An argument for continuity', History and Theory 25(2), 117-131. http://dx.doi.org/10.2307/2505301

Chikwava, B., 2009, Harare north, Jonathan Cape, London.

Chingono, J., 2006, Not another day, Weaver, Harare.

Chinodya, S., 1982, Dew in the morning, Mambo Press, Gweru.

Gomo, M., 2010, A fine madness, Ayebia Clarke, Banbury.

Hove, C., 1988, Bones, Baobab, Harare.

Hove, C., 2003, Blind moon, Weaver, Harare.

Mtizira, N., 2008, The Chimurenga Protocol, Botshelo, Gaborone.

Mugabe, R., 2001, Inside the Third Chimurenga, Department of Information and Publicity, Harare.

Mungoshi, C., 1981, Waiting for the rain, Zimbabwe Publishing House, Harare.

Muponde, R., 2004a, 'The worm and the hoe: Cultural politics and reconciliation after the Third Chimurenga', in B. Raftopoulos \& T. Savage (eds.), Zimbabwe: Injustice and political reconciliation, pp. 176-192, Institute for Justice and Reconciliation, Cape Town.

Muponde, R., 2004b, 'Land as the text of Zimbabwean history', The Nordic Africa Institute, viewed 25 November 2012, from http://www.nai.uu.se/ research/finalized_projects/cultural_images_in_and_of/zimbabwe/literature/ muponde/

Mutswairo, S., 1978, Mapondera, soldier of Zimbabwe, Three Continents Press, Washington, DC.

Ndlovu-Gatsheni, S., 2011, The construction and decline of Chimurenga monologue in Zimbabwe: A study in resilience of ideology and limits of alternatives, viewed 18 December 2013, from http://www.africanafrican.com/folder17/alot more of african \& african american history23/Chimurenga/Sabelo-Ndlovu-Gatsheni-fullpaper.pdf

Pleßke, N., 2014, The intelligible metropolis: Urban mentality in contemporary London novels, Transcript Verlag, Bielefeld.

Primorac, R., 2006, The place of tears. The novel and politics in modern Zimbabwe, Taurus, London.

Primorac, R., 2007, 'The poetics of state terror in twenty-first century Zimbabwe', Interventions 9(3), 434-450. http://dx.doi.org/10.1080/13698010701618687

Raftopoulos, B., 2009, 'The crisis in Zimbabwe, 1998-2008', in B. Raftopoulos \& A. Mlambo (eds.), Becoming Zimbabwe: A history from the pre-colonial period to 2008, pp. 201-232, Weaver Press, Harare.

Ranger, T., 2004, 'Nationalist historiography, patriotic history and the history of the nation: The struggle over the past in Zimbabwe', Journal of Southern African Studies 30(2), 215-234. http://dx.doi.org/10.1080/0305707042000215338

Said, E.W., 1993, Culture and imperialism, Vintage, London.

Samkange, S.J.T., 1966, On trial for my country, Heinemann Educational Books, London.

Samkange, S.J.T., 1978, Year of the uprising, Heinemann Educational Books, London.

Scott, J.C., 1990, Domination and the arts of resistance, Yale University Press, New Haven.

Tekere, E., 2007, A lifetime of struggle, SAPES, Harare.

Tendi, B.M., 2010, Making history in Mugabe's Zimbabwe: Politics, intellectuals and the media. Peter Lang, Bern.

Tiffin, H., 1995, 'Post-colonial literatures and counter-discourse', in B. Ashcroft, G. Griffiths \& H. Tiffin (eds.), The Post-colonial Studies Reader, pp. 95-98, Routledge, London.

Vera, Y., 1993, Nehanda, Baobab, Harare.

Wilkinson, S., 2006, Detective fiction in Cuban society and culture, Peter Lang, Bern.

ZANU-PF, 2008, 100 reasons to vote ZANU PF and Cde Robert Mugabe, ZANU-PF Information Department, Harare. 